\title{
Yogic LIFESTYLE
}

\section{S.Sridharan *}

"Life Style", in simple terms, is a modern day usage to connote how one is spending time including the behavior and attitudes. This is related to the purpose of life as envisioned by an individual. Mostly the purpose of life is limited by the station of life, i.e. student, employment and earning, family life and retirement. Today, a student wants to get good grades and thus focuses on the marks/grades. Even, studying is oriented towards that goal and particularly to place one at the gateway of employment. The purpose of employment is directly linked to the earnings, which in turn is to increase the comforts of life. Today a family life is a social compulsion. At every stage there are limited goals and thus 'life style' is linked to the goals. A student today spends more time in the night to study and the cycle of the day is thus changed. There is hardly any time for physical activity leave alone good exercise pattern. An employed person's clock is decided by his employer and often it could relate to a different time zone. A family person has hardly time left to introspect.

The ancients put the station of life under the term 'Ashrama' and divided it as, Brahmacharya, Grahasta, VAnaprasta and Sanyasa. The ancient model of 'Ashrama' was based on the four purpose of life (purushArtAs) which are "dharma, artha, kAma and moksha", which can translate to "discipline, wealth, desire and liberation". The ultimate purpose of life for the ancients was "liberation", liberation from the cycle of birth and death. Thus the ancient 'life style' took into account the ultimate purpose of 'liberation' without compromising on the pleasure of living within the discipline.

There are various paths for 'liberation' and one can choose according to their background, taste and ability. One can choose the path of action or path of knowledge or path of devotion or path of total surrender. However, any of these paths need the basic discipline and this is provided by "Yoga"; the discipline at the body and mind level. Without this discipline no one can progress in any of these paths. They merely become attempts often leading to frustration.

Yoga has a well laid out path of discipline structured to address all the dimensions of the human system, i.e. annamaya (body), prANamaya (breath), manomaya (mind), vigyanamaya (ego/intellect) and anandamaya (emotion).

Yogic lifestyle thus disciplines the practitioner at all the levels and makes him/her fit for undertaking the spiritual path. Even if one does not have a spiritual inclination mere 'yogic lifestyle' will lead the person on the path of realisation, by providing a healthy body and mind. A healthy and perfect mind is the best tool for 'Self realisation'.

There are various models of 'yogic lifestyle' based on various traditions and the path of realisation. From the Vedas, Sages culled out the points required for 'life style' and gave them in the form of 'Agamas' and 'kalpa sUtras'. There are various divisions in them based on the particular Veda, i.e. Rg, Yajur, Sama or Atharva or the particular deity such as Vishnu, Shiva, Shakti, etc.

All of them have certain common regulations such as what should be done in what part of the day, etc. For all these regulations, there are certain common activities which will include Yogic tools of Asana, Pranayama and Dhyana.

One such model is called "Panca kAla ParAyanam", which literally means "the activities to be filled with in the five parts of the day". This is a part of the "PAncha RAtra Agama". Here a day is divided into 5 parts and the activities are assigned to each part.

\footnotetext{
* Yogacharya S.Sridharan, Trustee, Krishnamacharya Yoga Mandiram; Member, Governing Body of Morarji Desai National Institute of Yoga,

New Delhi
} 


\begin{tabular}{|l|l|l|}
\hline \multicolumn{1}{|c|}{ Part of the day } & \multicolumn{1}{|c|}{ What is to be done } & \multicolumn{1}{c|}{ Name in the Agama } \\
\hline (1) Early morning & $\begin{array}{l}\text { Getting up and getting prepared for } \\
\text { the day }\end{array}$ & Abhigamanam \\
\hline (2) Forenoon & $\begin{array}{l}\text { Collect things required for worship } \\
\text { or spending time for earning things }\end{array}$ & UpAdAnam \\
\hline (3) Noon & Worship & Ijya \\
\hline (4) Afternoon & $\begin{array}{l}\text { Study of scriptures towards 'Self } \\
\text { Realisation' }\end{array}$ & SvAdhyaya \\
\hline (5) Night & $\begin{array}{l}\text { Yoga (Here the word denotes sleep } \\
\text { when the Individual Self merges } \\
\text { with the Supreme Self) }\end{array}$ & Yoga \\
\hline
\end{tabular}

This model, even though it is practiced by a limited number of people in some form or other, cannot have direct relevance for practicing in the same way. But this can be adapted.

A yogic life style is not just practice of yoga in the morning or in some part of the day depending upon the convenience. It is to integrate the yoga quantitatively and qualitatively into every part of the day. For example, in the above said model, practice of Asana, Pranayama and Dhyana will be found in at least four parts of the day except in the second part which is the part of employment. Here also the principles of Yama will be observed. The Early morning part will have a large portion of Sun Meditation including doing postures, breathing and meditation. In the Noon, worship will include largely meditation. In the afternoon, there will be recitation of scriptures and in the night a small Pranayama to end the day.

To adapt it to modern life style will be to take up practice of a full length course of Asana and Pranayama and Meditation first thing in the morning. This can include Surya Namaskar and important postures such as MahAmudra, etc. The Pranayama could be "Nadi Sodhana Pranayama". On return one can do a Pranayama course aimed at "unwinding' and 'relaxation'. This will have a longer exhalation and hold and can be "Chandra bhedana Pranayama". Before hitting the bed, one can do a small Meditation to end the day properly and prepare for the next day. This can include relaxation of parts of the body and visualizing a nice natural scene or form of Divinity of choice and hear soothing music.

A yogic life style, adapted to an individual, is possible in today's contest and will bestow the benefit of a good physical and mental health turning one inwards towards 'Self Realisation' by still being a part of family life. 